\title{
Evaluation of Cowpea Genotypes for Virus Resistance Under Natural Conditions in Uganda
}

\author{
Emmanuel K. Mbeyagala ${ }^{1,2}$, Blasio S. Mukasa ${ }^{1}$, Phinehas Tukamuhabwa ${ }^{1} \&$ Jenipher Bisikwa $^{1}$ \\ ${ }^{1}$ School of Agricultural Sciences, Makerere University, Kampala, Uganda \\ ${ }^{2}$ National Semi Arid Resources Research Institute (NaSARRI), Uganda \\ Correspondence: Jenipher Bisikwa, School of Agricultural Sciences, Makerere University P.O. Box 7062 \\ Kampala, Uganda. Tel: 256-414-533-580. Email: jbisikwa@caes.mak.ac.ug; bisikwa@gmail.com
}

Received: June 3, 2014 Accepted: August 12, 2014 Online Published: September 15, 2014

doi:10.5539/jas.v6n10p176

URL: http://dx.doi.org/10.5539/jas.v6n10p176

\begin{abstract}
Cowpea (Vigna unguiculata L. Walp) is an important grain legume in most parts of Sub Saharan Africa. However, viral diseases are a major limiting production factor causing significant yield losses. An experiment was conducted to evaluate the reaction of 105 different cowpea genotypes to viral infection in different agro-ecological zones of Uganda. The aim was to identify genotypes that could serve as sources of resistance to virus infection. Virus infection in these experiments occurred naturally through insect vectors. Results showed that there were significant differences in disease reaction among genotypes within and among agro-ecological zones in terms of Area Under Disease Progress Curve (AUDPC) and incidence. Interactions of genotype by season (GXS), genotype by location (GXL) and genotype by location by season (GXLXS) also significantly affected reaction to viral infection among genotypes. Introduced cowpea genotypes exhibited a more susceptible viral disease reaction compared to the landraces over the two seasons in the three locations. A number of landraces such as WC32, WC18, NE43, NE15, WC35B consistently showed resistance to virus infection in the three locations and therefore could be good sources of resistance. Low disease pressure (AUDPC) was also recorded on SECOW2W (released variety) as reported by previous studies. The landraces also gave consistently higher grain yield values compared to the introduced genotypes. Overall, data from this study showed that locally adapted cowpea genotypes offer resistance to virus infection and may be desirable germplasm for Ugandan cowpea breeding programs.
\end{abstract}

Keywords: agroecological zone, AUDPC, cowpea, genotypes, incidence, natural, resistance, virus

\section{Introduction}

Cowpea (Vigna unguiculata L. Walp) is a grain legume crop with high protein, minerals and vitamins and is utilized as a fresh vegetable (pods and leaves), and as fodder. Cowpea is an early maturing crop and therefore helps reduce the "hunger period" that often occurs prior to harvest in farming communities (Singh et al., 2002; Timko et al., 2007a). It is an important source of income especially to the rural households after selling the grain and the fresh leaves (Isubikalu et al., 1999; Singh et al., 2002; Timko et al., 2007a). Cowpea curbs erosion through its rapid ground coverage and fixes atmospheric nitrogen thus improving soil fertility (Singh et al., 2002; Tarawali et al., 2002; Casky et al., 2002). In Uganda, cowpea is an important food security crop especially in the eastern and northern regions where up to $90 \%$ of the crop is grown (Adipala et al., 1999).

Wherever cowpea is grown, viral diseases are a major constraint to production and yield (Bashir \& Hampton, 1996). More than 20 viruses affect cowpea production worldwide (Thottappilly \& Rossel, 1985). Yield losses of almost $90 \%$ or even total crop failure have been reported (Kaiser \& Mossahebi, 1975; Raheja \& Leleji, 1974). In Uganda, the main viruses infecting cowpea are; Cowpea aphid borne mosaic (CABMV), Cucumber mosaic virus (CMV), Cowpea mild mottle virus (CPMMV) and Cowpea severe mosaic virus (CPSMV) (Amayo et al., 2012; Orawu et al., 2005; Edema et al., 1997). The seed-borne nature of these viruses renders them very destructive to emerging seedlings and insect vectors can spread these further (Ndiaye et al., 1993; Bashir et al., 2002). These viruses are transmitted by several insect species in a non persistent manner and therefore use of insecticides is not an effective method of control (Umaharan et al., 1997). Genetic resistance, therefore, is the best alternative in reducing crop losses due to these diseases. 
To identify host resistance, it is important to evaluate different genotypes under field conditions in different environments (Goenaga et al., 2011; Maphosa et al., 2013; Oloka et al., 2008). This study was therefore undertaken to study the reaction of 105 cowpea genotypes to natural virus infection to identify sources of resistance for breeding.

\section{Materials and Methods}

\subsection{Experimental Sites and Their Characteristics}

The study was conducted in 2012 during two seasons, herein referred as 2012A and 2012B, at three locations in Uganda that are known to grow cowpeas extensively (Table 1). These locations have differing edaphic characteristics, land use types and cropping systems, and climatic conditions that influence crop growth, vector populations and virus disease development.

Table 1. Altitude and climatic data at three experimental sites in Uganda

\begin{tabular}{cccccc}
\hline Site & ${ }^{*}$ AEZ & Altitude (m.a.s.l) & $\begin{array}{c}{ }^{4} \text { Average Minimum Annual } \\
\text { Temperature }\left({ }^{\circ} \mathrm{C}\right)\end{array}$ & $\begin{array}{c}{ }^{4} \text { Average Maximum Annual } \\
\text { Temperature }\left({ }^{\circ} \mathrm{C}\right)\end{array}$ & $\begin{array}{c}{ }^{4} \text { Annual Mean } \\
\text { Rainfall }(\mathrm{mm})\end{array}$ \\
\hline Serere & NMF1 & 1,110 & 17.7 & 30.1 & 1,357 \\
Budaka & SELKB2 & 1,142 & 16.8 & 29.3 & 1,198 \\
Tororo & LVIC 3 & 1,204 & 16.0 & 28.7 & 1,484 \\
\hline
\end{tabular}

* $\overline{\text { Agroecological zone, }{ }^{1} \text { Northern Moist Farmlands, }{ }^{2} \text { Southern and Eastern Lake Kyoga Basin, }{ }^{3} \text { Lake Victoria }}$ Crescent and Mbale Farmlands.

Source: ${ }^{4}$ Meteorological stations at the experimental sites in 2012 and ${ }^{*}$ AEZ delineation according to Wortmann and Eledu (1999).

\subsection{Genotypes and Experimental Design}

A total of 105 cowpea genotypes that included landraces (82), commercially released varieties (1) and introductions (22). The introductions were provided by the International Institute of Tropical Agriculture (IITA) (Table 2). The landraces were collected from the northern and eastern regions (NE), western and central regions (WC) of Uganda.

At all sites, the fields were ploughed twice before harrowing to prepare a fine seedbed before planting. Each genotype was planted in two rows measuring $4 \mathrm{~m}$ long with spacing of $60 \mathrm{~cm}$ between rows and $30 \mathrm{~cm}$ between plants within rows. The experimental design was $\alpha$-design (incomplete block design) as described by Patterson and Williams (1976a) generated using the ALPHA program (http://www.designcomputing.net/gendex) with three replicates. In each season, experimental plots were kept free of weed by hoeing. Fertilizers and /or supplementary water through irrigation were not applied during the trials. Post flowering pests such as flower thrips (Megalurothrips sjostedti Trybom), pod borer (Maruca vitrata Fabricius) and pod sucking bugs were controlled by 3-4 sprays using Roket 44 EC (Profenofos $40 \%$ and Cypermethrin 4\%) starting from the budding stage. 
Table 2. Description of cowpea genotypes used in the study

\begin{tabular}{ccc}
\hline Genotype & Source & Type \\
\hline WC4 & WC & Landrace \\
WC41 & WC & Landrace \\
WC42 & WC & Landrace \\
WC44 & WC & Landrace \\
WC48 & WC & Landrace \\
WC5 & WC & Landrace \\
WC51 & WC & Landrace \\
WC52 & WC & Landrace \\
WC53 & WC & Landrace \\
WC55 & WC & Landrace \\
WC6 & WC & Landrace \\
WC62 & WC & Landrace \\
WC63 & WC & Landrace \\
WC64 & WC & Landrace \\
WC65 & WC & Landrace \\
WC66 & WC & Landrace \\
WC67 & WC & Landrace \\
WC67A & WC & Landrace \\
WC68 & WC & Landrace \\
WC69 & WC & Landrace \\
WC7 & WC & Landrace \\
MU20 & MAK & Landrace \\
NE53 & NE & Landrace \\
WC39 & WC & Landrace \\
\hline
\end{tabular}

$\mathrm{NE}=$ Northern and Eastern, Uganda; $\mathrm{WC}=$ Western and Central, Uganda; MAK $=$ Makerere University, Uganda; IITA = International Institute of Tropical Agriculture, Nigeria.

Table 2 continued. Description of cowpea genotypes used in the study

\begin{tabular}{ccccccccc}
\hline Genotype & Source & Type & Genotype & Source & Type & Genotype & Source & Type \\
\hline EBELAT & NE & Landrace & MU20B & MAK & Landrace & NE55 & NE & Landrace \\
IT00K-835-45 & IITA & Introduction & MU9 & MAK & Landrace & NE6 & NE & Landrace \\
IT03K-124 & IITA & Introduction & NE13 & NE & Landrace & NE67 & NE & Landrace \\
IT04K-219-2 & IITA & Introduction & NE15 & NE & Landrace & NE70 & NE & Landrace \\
IT04K-221-1 & IITA & Introduction & NE17 & NE & Landrace & NE71 & NE & Landrace \\
IT04K-227-4 & IITA & Introduction & NE18 & NE & Landrace & SECOW2W & NE & Cultivar \\
IT06K-121 & IITA & Introduction & NE19 & NE & Landrace & WC1 & WC & Landrace \\
IT06K-123-1 & IITA & Introduction & NE23 & NE & Landrace & WC10 & WC & Landrace \\
IT06K-124 & IITA & Introduction & NE30 & NE & Landrace & WC11 & WC & Landrace \\
IT06K-147-1 & IITA & Introduction & NE31 & NE & Landrace & WC12 & WC & Landrace \\
IT06K-154-1 & IITA & Introduction & NE32 & NE & Landrace & WC13 & WC & Landrace \\
\hline
\end{tabular}




\begin{tabular}{ccccccccc}
\hline IT06K-281-1 & IITA & Introduction & NE36 & NE & Landrace & WC15 & WC & Landrace \\
IT06K-91-11-1 & IITA & Introduction & NE37 & NE & Landrace & WC16 & WC & Landrace \\
IT07K-187-24 & IITA & Introduction & NE39 & NE & Landrace & WC17 & WC & Landrace \\
IT07K-188-49 & IITA & Introduction & NE4 & NE & Landrace & WC18 & WC & Landrace \\
IT07K-211-1-8 & IITA & Introduction & NE40 & NE & Landrace & WC2 & WC & Landrace \\
IT07K-243-1-5 & IITA & Introduction & NE41 & NE & Landrace & WC21 & WC & Landrace \\
IT07K-292-10 & IITA & Introduction & NE42 & NE & Landrace & WC26 & WC & Landrace \\
IT07K-299-4 & IITA & Introduction & NE43 & NE & Landrace & WC27 & WC & Landrace \\
IT07K-300-12 & IITA & Introduction & NE44 & NE & Landrace & WC29 & WC & Landrace \\
IT89KD-288 & IITA & Introduction & NE45 & NE & Landrace & WC30 & WC & Landrace \\
IT97K-499-35 & IITA & Introduction & NE46 & NE & Landrace & WC32 & WC & Landrace \\
IT98K-503-1 & IITA & Introduction & NE48 & NE & Landrace & WC33 & WC & Landrace \\
MU09B & MAK & Landrace & NE49 & NE & Landrace & WC35A & WC & Landrace \\
MU15 & MAK & Landrace & NE5 & NE & Landrace & WC35B & WC & Landrace \\
MU17 & MAK & Landrace & NE50 & NE & Landrace & WC35C & WC & Landrace \\
MU19 & MAK & Landrace & NE51 & NE & Landrace & WC36 & WC & Landrace
\end{tabular}

$\mathrm{NE}=$ Northern and Eastern, Uganda; $\mathrm{WC}=$ Western and Central, Uganda; MAK = Makerere University, Uganda; IITA = International Institute of Tropical Agriculture, Nigeria.

\subsection{Data Collection Method}

For each trial, data were collected at 14-days interval starting three weeks after planting (WAP) until the appearance of the first ripe pods. Viral disease incidence was recorded on all plants per plot while severity was recorded on ten randomly selected plants in a plot. Disease severity was based on visual estimation of the diseased plants as manifested by the different symptoms on a modified scale of $1-5$ where $1=$ no symptoms on all leaves, $2=$ slight symptoms ( 1 to $25 \%$ of the leaves infected), 3 = moderate symptoms ( 26 to $50 \%$ leaves infected), $4=$ prominent symptoms with stunting (51 to $75 \%$ of leaves infected), $5=$ highly severe symptoms with stunting ( $>75 \%$ of leaves infected) (Gumedzoe et al., 1997).

\subsection{Statistical Analysis}

Disease severity data were used to compute area under disease progress curve (AUDPC) as described by Campbell and Madden (1990).

$$
\mathrm{AUDPC}=\sum_{i=1}^{n-1}\left(\frac{Y_{i}+Y_{i+1}}{2}\right)\left(t_{i+1}-t_{i}\right)
$$

where; $n=$ number of successive readings, $Y_{i}=$ disease severity at time $i, t_{i}=$ number of days after the first observation on assessment date i. Data were also recorded on number of days to $50 \%$ flowering (midbloom), number of days to maturity and yield. Data was subjected to analysis of variance (ANOVA) using the linear mixed models (REML) in Genstat discovery Edition 4 (http://discovery.genstat.co.uk) and R version 3.1.0 (R core team, 2014). Mean AUDPC and incidence per genotype were computed per location as well as per season and genotype.

\section{Results}

Area under disease progress and disease incidence were high in Budaka and lowest in Tororo over the two seasons (Table 3). In the first season (2012A), lowerAUDPC and disease incidence were recorded than in the second season (2012B). Overall, mean AUDPC was lower in 2012A than in 2012B, with Budaka 12A recording the highest values followed by Tororo12A and then Serere12A. In 2012B, Budaka12B had the highest disease severity followed by Serere 12B and lastly Tororo12B. Based on genotype source, cowpea genotypes from IITA had higher AUDPC and disease incidence values than genotypes from Uganda (Table 4). Among the Ugandan genotypes, accessions from the western and central regions of the country had lower disease levels (Table 4). 
Table 3. Mean AUDPC and mean disease incidence across locations

\begin{tabular}{cccc}
\hline Location & Season & AUDPC & Incidence \\
\hline Budaka & 2012A & 34.8 & 28 \\
Budaka & 2012B & 79.9 & 62.6 \\
Serere & 2012A & 31.1 & 25.4 \\
Serere & 2012B & 78.2 & 61.2 \\
Tororo & 2012A & 31.5 & 28.5 \\
Tororo & 2012B & 65.0 & 34.9
\end{tabular}

Table 4. Mean AUDPC and mean disease incidence according to source of planting material

\begin{tabular}{cccc}
\hline Source & Location & AUDPC & Incidence \\
\hline IITA & Budaka & 77.3 & 66.9 \\
MAK & Budaka & 58.9 & 45.0 \\
NE & Budaka & 54.5 & 42.1 \\
WC & Budaka & 50.9 & 38.6 \\
IITA & Serere & 65.2 & 61.3 \\
MAK & Serere & 53.9 & 48.2 \\
NE & Serere & 55.0 & 44.7 \\
WC & Serere & 51.2 & 37.7 \\
IITA & Tororo & 54.1 & 46.8 \\
MAK & Tororo & 49.5 & 39.5 \\
NE & Tororo & 45.6 & 28.1 \\
WC & Tororo & 45.5 & 25.9
\end{tabular}

$\mathrm{NE}=$ Northern and Eastern; $\mathrm{WC}=$ Western and Central; MAK $=$ Makerere University collection; IITA = International Institute of Tropical Agriculture, Nigeria.

Analysis of variance showed significant differences among genotypes, seasons and locations for AUDPC. The site $\mathrm{x}$ season, site $\mathrm{x}$ genotype, season $\mathrm{x}$ genotype and site $\mathrm{x}$ season $\mathrm{x}$ genotype interactions were also highly significant (Table 5).

Table 5. Analysis of variance for area under disease progress curve among cowpea genotypes evaluated for two seasons

\begin{tabular}{llll}
\cline { 2 - 3 } Source of variation & d.f. & Mean squares \\
\cline { 2 - 3 } Site & 2 & $135.7^{* * *}$ \\
Season & 1 & $8074.3^{* * *}$ \\
Genotype & 104 & $1569.1^{* * *}$ \\
& Site xSeason & 2 & $155.9^{* * *}$ \\
& Site x Genotype & 208 & $427^{* * *}$ \\
& Season x Genotype & 104 & $373.9^{* * *}$ \\
& Site x Season x Genotype & 208 & $268.9^{* *}$ \\
\cline { 2 - 2 }$=$ significant at 0.001 and 0.003 respectively. & &
\end{tabular}


Among locations, analysis of variance indicated that there were significant genotype, season and genotype $\mathrm{x}$ season interaction for AUDPC and disease incidence (Table 6). However, seasonal differences had the strongest effects on both AUDPC and disease incidence. The effects of genotype and genotype x season on AUDPC were greater in Budaka than for Serere and Tororo.

Table 6. Variation of AUDPC and incidence across experimental locations

\begin{tabular}{|c|c|c|c|c|c|c|c|}
\hline \multirow{2}{*}{ Source of variation } & \multirow{2}{*}{ df } & \multicolumn{3}{|c|}{ AUDPC Mean squares } & \multicolumn{3}{|c|}{ Incidence Mean squares } \\
\hline & & Budaka & Serere & Tororo & Budaka & Serere & Tororo \\
\hline Genotype & 104 & $1158.8^{* * *}$ & $352.9^{* * *}$ & $518.3^{* * *}$ & $1313.4^{* * *}$ & $780.1^{* * *}$ & $890.1^{* * *}$ \\
\hline Season & 1 & $307183.2^{* * *}$ & $330899.6^{* * *}$ & $183031.3^{* * *}$ & $183902.1^{* * *}$ & $223977.4^{* * *}$ & $6659.1^{* * *}$ \\
\hline Genotypex season & 104 & $298.1^{* * *}$ & $78.4^{* *}$ & $245.6^{* * *}$ & $253.3^{* *}$ & $256.5^{* * *}$ & $264.2^{* * *}$ \\
\hline Residual & 300 & 129.3 & 59.8 & 116.4 & 193.4 & 140.7 & 166.7 \\
\hline
\end{tabular}

${ }^{* * *}=$ significant at 0.001 level, ${ }^{* *}=$ significant at 0.05 level.

Mean AUDPC for the 105 genotypes screened for reaction under natural infestation are shown in Table 7. Average AUDPC across the three locations over the two seasons, ranged from 39.4 (on genotype WC48) to 94.9 (genotype NE46). It is evident from the table that none of the genotypes evaluated were immune. The introduced germplasm from IITA exhibited more susceptible reaction than the local accessions (Table 7 and Figure 1). Among the local genotypes, the accessions WC48, MU19 and NE43 from the western and central region, Makerere University and Northern and Eastern Uganda respectively had the lower AUDPC. A range of typical virus symptoms were also observed on most genotypes during evaluation such as; leaf mosaic, necrosis, chlorosis, vein clearing, vein banding, purpling, leaf curling, leaf deformation, and blotching.

Table 7. Overall Cowpea genotype reaction based on AUDPC

\begin{tabular}{|c|c|c|c|c|c|c|c|}
\hline \multicolumn{4}{|c|}{ Location } & \multicolumn{4}{|c|}{ Location } \\
\hline Genotype & Budaka & Serere & Tororo & Genotype & Budaka & Serere & Tororo \\
\hline EBELAT & 62.7 & 59.1 & 51.9 & MU20 & 92.6 & 61.3 & 67.6 \\
\hline IT00K-835-45 & 62.3 & 63.8 & 41.2 & MU20B & 60.8 & 51.9 & 43.4 \\
\hline IT03K-124 & 71.2 & 62.8 & 54.4 & MU9 & 42.9 & 52.3 & 42.8 \\
\hline IT04K-219-2 & 63.8 & 67.2 & 54.5 & NE13 & 52.4 & 56.4 & 44.0 \\
\hline IT04K-221-1 & 61.8 & 63.5 & 72.3 & NE15 & 46.6 & 48.8 & 31.0 \\
\hline IT04K-227-4 & 68.4 & 68.2 & 41.4 & NE17 & 48.5 & 50.5 & 37.1 \\
\hline IT06K-121 & 86.5 & 67.9 & 68.0 & NE18 & 48.9 & 52.4 & 43.4 \\
\hline IT06K-123-1 & 73.1 & 66.3 & 61.1 & NE19 & 68.7 & 53.9 & 56.6 \\
\hline IT06K-124 & 70.5 & 56.6 & 56.5 & NE23 & 52.2 & 52.1 & 37.8 \\
\hline IT06K-147-1 & 76.2 & 55.9 & 67.5 & NE30 & 48.6 & 53.4 & 45.8 \\
\hline IT06K-154-1 & 79.9 & 58.8 & 42.4 & NE31 & 57.8 & 53.5 & 50.8 \\
\hline IT06K-281-1 & 69.2 & 62.2 & 47.3 & NE32 & 48.5 & 51.9 & 38.8 \\
\hline IT06K-91-11-1 & 85.0 & 82.2 & 80.7 & NE36 & 46.0 & 51.4 & 51.4 \\
\hline IT07K-187-24 & 74.6 & 72.6 & 50.8 & NE37 & 47.8 & 46.2 & 44.3 \\
\hline IT07K-188-49 & 76.2 & 69.6 & 69.2 & NE39 & 46.7 & 53.6 & 45.4 \\
\hline IT07K-211-1-8 & 60.2 & 57.8 & 62.4 & NE4 & 59.7 & 52.7 & 54.4 \\
\hline IT07K-243-1-5 & 65.1 & 63.8 & 48.8 & NE40 & 61.0 & 57.1 & 44.1 \\
\hline IT07K-292-10 & 81.8 & 47.0 & 66.0 & NE41 & 49.0 & 52.4 & 47.5 \\
\hline
\end{tabular}




\begin{tabular}{cccccccc}
\hline IT07K-299-4 & 77.1 & 65.6 & 44.2 & NE42 & 52.4 & 53.8 & 41.3 \\
IT07K-300-12 & 75.2 & 66.7 & 52.9 & NE43 & 48.9 & 47.6 & 30.7 \\
IT89KD-288 & 70.7 & 60.8 & 59.8 & NE44 & 52.9 & 51.7 & 40.4 \\
IT97K-499-35 & 80.6 & 66.1 & 39.5 & NE45 & 54.9 & 50.8 & 46.0 \\
IT98K-503-1 & 69.8 & 59.9 & 53.1 & NE46 & 101.7 & 92.4 & 90.5 \\
MU09B & 43.8 & 57.4 & 49.5 & NE48 & 48.9 & 48.8 & 42.5 \\
MU15 & 47.0 & 51.4 & 55.5 & NE49 & 56.5 & 57.3 & 52.0 \\
MU17 & 59.5 & 55.1 & 52.6 & NE5 & 50.5 & 52.2 & 43.9 \\
MU19 & 44.6 & 47.6 & 41.3 & NE50 & 42.3 & 56.2 & 41.2 \\
NE51 & 51.5 & 47.7 & 48.9 & NE70 & 55.0 & 59.0 & 44.2 \\
NE53 & 53.9 & 51.8 & 47.3 & NE71 & 65.0 & 52.0 & 58.4 \\
NE55 & 63.6 & 52.8 & 43.5 & SECOW2W & 46.6 & 48.3 & 39.6 \\
NE6 & 56.1 & 47.6 & 43.4 & WC1 & 43.4 & 50.8 & 52.5 \\
NE67 & 48.8 & 50.8 & 44.1 & WC10 & 57.2 & 49.4 & 50.1 \\
\hline
\end{tabular}

Table 7 continued. Overall Cowpea genotype reaction based on AUDPC

\begin{tabular}{|c|c|c|c|c|c|c|c|}
\hline \multicolumn{4}{|c|}{ Location } & \multicolumn{4}{|c|}{ Location } \\
\hline Genotype & Budaka & Serere & Tororo & Genotype & Budaka & Serere & Tororo \\
\hline WC11 & 48.3 & 53.0 & 49.7 & WC4 & 48.5 & 53.8 & 48.5 \\
\hline WC12 & 42.1 & 55.3 & 42.2 & WC41 & 50.8 & 51.4 & 48.1 \\
\hline WC13 & 62.7 & 55.0 & 42.0 & WC42 & 51.2 & 54.2 & 51.7 \\
\hline WC15 & 57.6 & 51.4 & 46.5 & WC44 & 49.2 & 50.5 & 48.8 \\
\hline WC16 & 57.9 & 50.5 & 58.8 & WC48 & 42.5 & 45.6 & 30.0 \\
\hline WC17 & 55.2 & 48.5 & 44.8 & WC5 & 56.3 & 55.1 & 52.5 \\
\hline WC18 & 42.7 & 49.6 & 42.2 & WC51 & 51.8 & 48.9 & 39.2 \\
\hline WC2 & 48.4 & 45.7 & 43.2 & WC52 & 62.8 & 46.3 & 54.6 \\
\hline WC21 & 46.2 & 48.7 & 44.0 & WC53 & 46.9 & 47.4 & 44.0 \\
\hline WC26 & 48.0 & 53.1 & 44.7 & WC55 & 59.1 & 48.5 & 41.7 \\
\hline WC27 & 44.9 & 51.1 & 47.3 & WC6 & 61.2 & 54.2 & 48.3 \\
\hline WC29 & 49.4 & 47.6 & 42.4 & WC62 & 60.9 & 50.2 & 47.8 \\
\hline WC30 & 47.6 & 53.5 & 51.2 & WC63 & 43.5 & 50.9 & 42.7 \\
\hline WC32 & 44.4 & 54.3 & 38.0 & WC64 & 55.9 & 48.8 & 50.0 \\
\hline WC33 & 41.4 & 46.9 & 52.6 & WC65 & 48.1 & 53.2 & 45.2 \\
\hline WC35A & 39.5 & 51.1 & 42.9 & WC66 & 47.7 & 50.7 & 47.5 \\
\hline WC35B & 54.0 & 49.7 & 33.0 & WC67 & 49.8 & 53.1 & 51.3 \\
\hline WC35C & 40.4 & 50.3 & 44.5 & WC67A & 46.0 & 54.6 & 42.0 \\
\hline WC36 & 60.5 & 51.4 & 47.5 & WC68 & 54.9 & 49.4 & 54.1 \\
\hline \multirow[t]{2}{*}{ WC39 } & 44.6 & 50.3 & 42.5 & WC69 & 60.3 & 51.4 & 47.5 \\
\hline & & & & WC7 & 67.0 & 52.5 & 59.6 \\
\hline
\end{tabular}




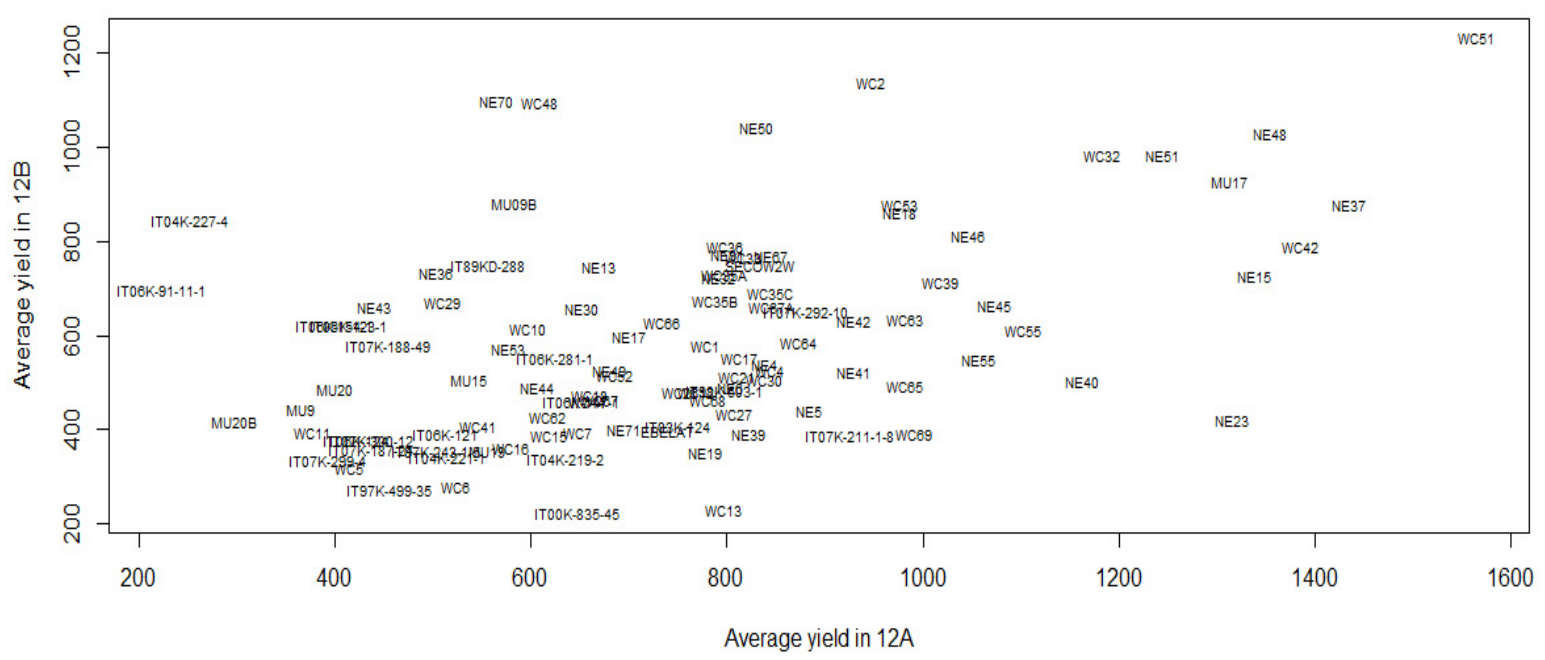

Figure 1. Relationship of mean yield (kg/ha) by genotypes across 2012A and 2012B

Number of days to $50 \%$ flowering over the two seasons ranged from 45 days to 73 days in Budaka, 39 days to 63 days in Serere and 42 days to 67 days in Tororo. The average number of days to $50 \%$ flowering in 2012A was 57 days, 44 days and 53 days for Budaka12A, Serere12A and Tororo12A respectively. In 2012B, the average number of days to $50 \%$ flowering was 52 days, 54days and 52 days in Budaka12B, Serere12B and Tororo12B respectively (Table 8).

Table 8 . Average number of days to 50\%flowering, maturity and average yield across study sites in 2012A and 2012B

\begin{tabular}{ccccc}
\hline Season & Site & $\begin{array}{c}\text { Mean number of } \\
\text { days to Midbloom }\end{array}$ & $\begin{array}{c}\text { Mean number of days } \\
\text { to Maturity }\end{array}$ & Mean Yield (kg/ha) \\
\hline 12A & Budaka & 56.9 & 88.6 & 1529.3 \\
$12 \mathrm{~A}$ & Serere & 43.6 & 81.2 & 187.3 \\
$12 \mathrm{~A}$ & Tororo & 53.3 & 85.2 & 565.9 \\
$12 \mathrm{~B}$ & Budaka & 51.9 & 73.5 & 522.6 \\
12B & Serere & 53.5 & 80.5 & 899.4 \\
$12 \mathrm{~B}$ & Tororo & 52.1 & 88.5 & 344.8 \\
\hline
\end{tabular}

Number of days to maturity across the two seasons ranged from 69 days to 101 days in Budaka, 71 days to 88 days in Serere and 67 days to 99 days in Tororo. Average number of days to maturity in 2012A was 87 days in Budaka, 81 days in Serere and 85 days in Tororo while in 2012B, the average number of days to maturity was 74 days, 81 days and 89 days respectively in Budaka, Serere and Tororo respectively (Table 8).

Yield over the two seasons ranged from $25 \mathrm{~kg} / \mathrm{ha}$ to $3000 \mathrm{~kg} / \mathrm{ha}$ in Budaka, $8.3 \mathrm{~kg} / \mathrm{ha}$ to $2650 \mathrm{~kg} / \mathrm{ha}$ in Serere and $25 \mathrm{~kg} / \mathrm{ha}$ to $2708 \mathrm{~kg} / \mathrm{ha}$ in Tororo. In Budaka, higher average yields were recorded in $2012 \mathrm{~A}(1529 \mathrm{~kg} / \mathrm{ha})$ compared to $523 \mathrm{~kg} / \mathrm{ha}$ obtained in 2012B. In Serere, there were higher yields in $2012 \mathrm{~B}(899 \mathrm{~kg} / \mathrm{ha})$ compared to $187 \mathrm{~kg} / \mathrm{ha}$ in 2012A while in Tororo, higher yields were obtained in $2012 \mathrm{~A}$ (566 kg/ha) compared to $345 \mathrm{~kg} / \mathrm{ha}$ in 2012B (Table 8). A plot of yield by genotypes across the two seasons showed that there were huge season to season differences for among genotypes (Figure 2). From the plot, some genotypes were consistently high yielding across the two seasons such as WC51, NE48, WC32, NE51 and MU17 while some were consistently low yielding such as IT07K-299-4 and WC5. Some genotypes performed better in 12A such as NE23, NE40 and NE15 while IT04K-227-4 and 1T06K-91-11-1 were better in 12B than 12A. 

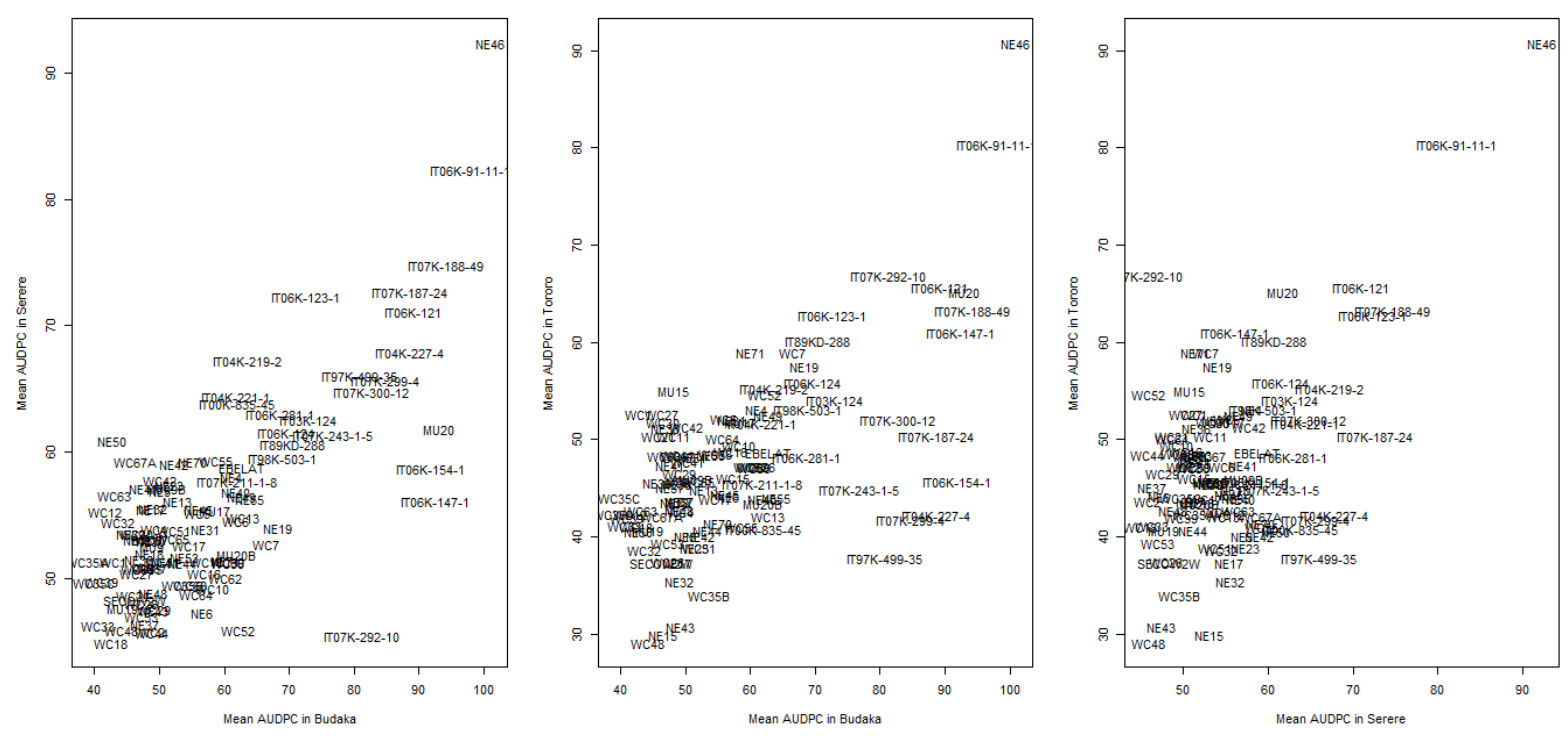

Figure 2. Variation of AUDPC by genotypes across study sites

Across the three study sites, local genotypes WC51, and NE48 gave consistently higher mean yield values while introduced genotypes such as IT97K-499-35, IT00K-835-45, and IT07K-299-4 were consistently low yielding (Figure 3). There was also yield variability among genotypes when two sites were compared for instance genotypes WC51, NE50, NE48, SECOW2W and WC2 gave higher yields both in Budaka and Serere while genotypes IT97K-499-35, IT04K-219-2, MU20B, WC13 and IT07K-300-12 gave consistently low yields in both locations. Comparing Budaka and Tororo, genotypes WC32, MU17, NE48 and WC42 registered higher yields while IT04K-221-1, IT97K-499-35, MU20, IT07K-187-24 and IT07K-299-4 gave low yields in both locations. For Serere and Tororo, higher yields were obtained from WC51 and NE51 genotypes while lower yield values were obtained from IT04K-221-1 and IT97K-499-35.
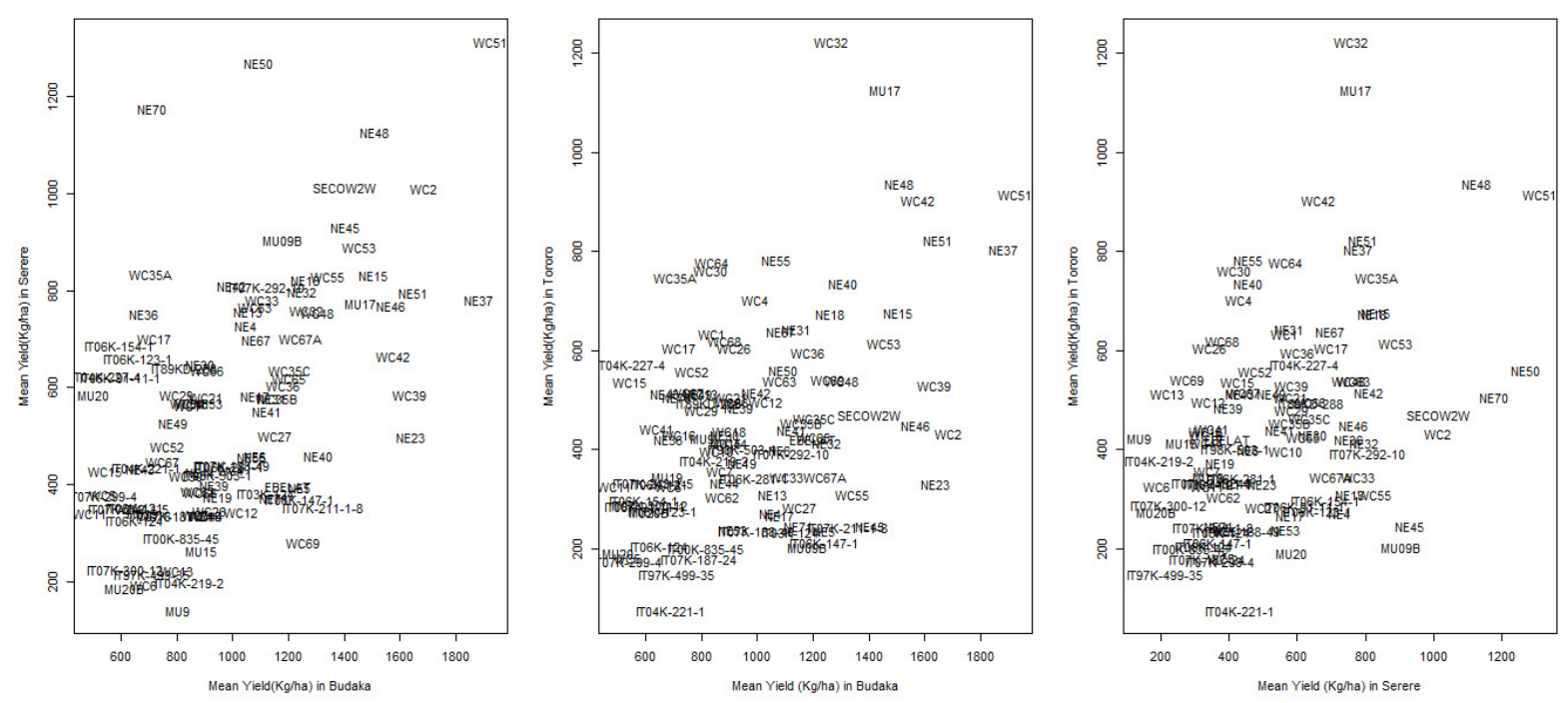

Figure 3. Relationship of mean yield $(\mathrm{kg} / \mathrm{ha})$ by genotypes across study sites

\section{Discussion}

There was variation in disease pressure across sites and seasons with higher AUDPC recorded in 2012B than in 2012A. These differences can be attributed to the influence of environmental conditions such as rainfall, temperature and relative humidity (Kaisser \& Mossahebi, 1975; Edema et al., 1997). Edema et al. (1997) 
however reported higher disease incidence in the first (wet season) than in the dry season. In our study, this could be attributed to rapid symptom development that normally occurs in dry conditions (Schuerger \& Hammer, 1995). Also under dry conditions, cowpea plants do not show considerable plasticity and recovery growth and hence are severely affected by viral infections (Booker et al., 2005).

During the trials at the three sites, the genotypes expressed a range of symptoms some appearing on the primary leaves shortly after germination. The symptoms ranged from leaf mosaic, necrosis, chlorosis, vein clearing, vein banding, purpling, leaf curling, leaf deformation, and blotching. It has been reported that symptom expression depends on the virus type or strain, genotype, species and plant age, time of the year and environmental conditions and some viruses cause similar or related symptoms (Shoyinka et al., 1997). Some symptoms such as mosaic, necrosis, chlorosis, vein banding, stunted growth, leaf deformation, and mottling are associated with viruses such as Cowpea aphid borne mosaic virus (CABMV), Blackeye cowpea mosaic virus (BICMV), Cowpea yellow mosaic virus (CYMV) (Aliyu et al., 2012; Orawu, 2007).

Results from this study also show that with the exception of genotype NE46, most of the landraces and the released variety (SECOW2W) were either resistant or moderately resistant compared to the introduced genotypes. However, Orawu et al. (2012) found Ebelat (landrace) to be susceptible especially to Cowpea aphid borne mosaic virus (CABMV). In this study, the cowpea genotypes were screened for resistance to field viruses and therefore, genotypes such as WC32, WC18, NE43, NE15, WC35B and SECOW2W with low disease severity may offer multiple virus resistance. Breeding for disease resistance in cowpea is a complex problem because of the occurrence of multiple virus infections in a single field/plant (Amayo et al., 2012; Orawu et al., 2012; Shoyinka et al., 1997). However, most of these viruses are transmitted by the same vectors which offers an opportunity to utilize horizontal resistance to vector transmission in breeding programmes (Shoyinka et al., 1997). The development of resistant varieties would be the most effective and environmentally friendly means of controlling these viral diseases. In the course of developing varieties that are resistant to a particular disease, the breeder has to select a resistant individual as a parent. The gene(s) conferring resistance can then be transferred to a cultivated variety in order to obtain improved lines (Ogundiwin et al., 2002). There is no ecological restriction to viruses affecting cowpea and therefore screening of genotypes under natural field conditions in different agro-ecological conditions is critical for identifying resistant genotypes (Shoyinka et al., 1997). The introduced genotypes were more susceptible compared to the local genotypes. Differential response of genotypes is common in disease resistance screening and can be attributed to differences in environmental conditions, pathogen variability and virulence (Gremillion et al., 2011).

\section{Conclusion}

Overall, results from this study identified a number of local landraces in addition to the released variety (SECOW2W) as useful sources of resistance to cowpea viruses that can be used in the local breeding program. These include; WC32, WC18, NE43, NE15, WC35B. Follow up studies both in the field and green house involving high virus innoculum levels (by artificial inoculation) need to be undertaken to confirm the levels of resistance in these genotypes. This study also showed consistency among genotypes in reaction to virus infection in the three locations over the two seasons. These study sites are therefore ideal for future screening of genotypes for resistance or susceptibility to virus infection.

\section{Acknowledgements}

We are grateful to the McKnight Foundation for funding this study through the Collaborative Crop Research Program (CCRP). We are thankful to the Centre Managers of Tororo DATIC and Ikiki DATIC in Budaka district for offering land over the two seasons to conduct field experiments.

\section{References}

Adipala, E., Omongo, C. A., Sabiti, A., Obuo, J. E., Edema, R., Bua, B., \& Ogenga-Latigo, M. W. (1999). Pests and diseases on cowpea in Uganda: Experiences from a diagnostic survey. African Crop Science Journal, 7(4), 465-478. http://dx.doi.org/10.4314/acsj.v7i4.27740

Aliyu, T., Balogun, O., \& Kumar, L. (2012). Survey of the symptoms and viruses associated with cowpea (Vigna unguiculata (L.) Walp) in the agroecological zones of kwara state, Nigeria. Ethiopian Journal of Environmental Studies And Management, 5(4), 613-619. http://dx.doi.org/10.4314/ejesm.v5i4.S22

Amayo, R., Arinaitwe, A. B., Mukasa., S. B., Tusiime, G., Kyamanywa, S., Rubaihayo, P., \& Edema, R. (2012). Prevalence of viruses infecting cowpea in Uganda and their molecular detection. African Journal of Biotechnology, 11(77), 14132-14139. http://dx.doi.org/10.5897/AJB11.398 
Bashir, M., Ahmad, Z., \& Ghafoor, A. (2002). Cowpea aphid-borne mosaic potyvirus: A review. International Journal of Pest Management, 48(2), 155-168. http://dx.doi.org/10.1080/09670870110118722

Bashir, M., \& Hampton, R. O. (1996). Detection and identification of seed-borne viruses from cowpea (Vigna $\begin{array}{llllll}\text { unguiculata (L.) Walp.) } \quad \text { germplasm. } & \text { Plant }\end{array}$ http://dx.doi.org/10.1046/j.1365-3059.1996.d01-97.x

Booker, H. M., Umaharan, P., \& McDavid, C. R. (2005). Effect of Cowpea severe mosaic virus on crop growth characteristics and yield of cowpea. Plant Dis., 89, 515-520. http://dx.doi.org/10.1094/PD-89-0515

Campbell, C. L., \& Madden, L. V. (1990). Introduction to plant disease epidemiology. Wiley, New York, USA.

Carsky, R. J., Vanlauwe, B., \& Lyasse, O. (2002). Cowpea rotation as a resource management technology for cereal-based systems in the savannas of West Africa. In C. A. Fatokun, S. A. Tarawali, B. B. Singh, P. M. Kormawa, \& M. Tamò (Eds.), Challenges and opportunities for enhancing sustainable cowpea production (pp. 252-266). Proceedings of the World Cowpea Conference III held at the International Institute of Tropical Agriculture (IITA), Ibadan, Nigeria.

Edema, R., Adipala, E., \& Florini, D. A. (1997). Influence of season and cropping system on occurrence of cowpea diseases in Uganda. Plant Disease, 81, 465-468. http://dx.doi.org/10.1094/PDIS.1997.81.5.465

Goenaga, R., Gillaspie, A. G., \& Quiles, A. (2011). Field performance of cowpea genotypes grown under virus pressure in Puerto Rico. African Crop Science Journal, 19(2), 97-103. http://dx.doi.org/10.4314/acsj.v19i2.69860

Gremillion, S., Culbreath, A., Gorbet, D., Mullinix, B., Pittman, R., Stevenson, K., \& Condori, M. (2011). Field evaluations of leaf spot resistance and yield in Peanut genotypes in the united states and Bolivia. Plant Disease, 95, 263-268. http://dx.doi.org/10.1094/PDIS-06-10-0454

Gumedzoe, M. Y. D., Thottapily, G., \& Asselin, A. (1997). Occurrence of southern bean mosaic virus (SVMV) in Togo and its interaction with some cowpea cultivars. African Crop Science Journal, 5(2), 215-222.

Isubikalu, P., Erbaugh, J. M., Semana, A. R., \& Adipala, E. (1999). Influence of farmer production goals on cowpea pest management in eastern uganda: implications for developing IPM programes. African Crop Science Journal, 7(4), 539-548. http://dx.doi.org/10.4314/acsj.v7i4.27748

Kaiser, W. J., \& Mossahebi, G. H. (1985). Studies with cowpea aphid borne mosaic virus and its effect on cowpea in Iran. FAO Plant Protection Bulletin, 23(2),33-39.

Maphosa, M., Talwana, H., \& Tukamuhabwa, P. (2013). Assessment of comparative virulence and resistance in soyabean using field isolates of soyabean rust. Journal of Agricultural Science, 5(5), $249-257$. http://dx.doi.org/10.5539/jas.v5n5p249

Ndiaye, M., Bashir, M., Keller, K., \& Hampton, R. O. (1993). Cowpea viruses in Senegal, west Africa: identities, distribution, seed transmission and sources of resistance. Plant Dis., 77, 999-1003. http://dx.doi.org/10.1094/PD-77-0999

Ogundiwin, E., Thottappily, G., Akenova, M., Ekpo, E., \& Fatokun, C. (2002). Resistance to cowpea mottle carmovirus in Vigna Vexillata. Plant Breeding, 121, 517-520. http://dx.doi.org/10.1046/j.1439-0523.2002.00769.x

Oloka, H. K., Tukamuhabwa, P., Sengooba, T., \& Asundram, S. (2008). Reaction of exotic soybean germplasm to Phakopsora pachyrhizi in Uganda. Plant Dis., 92, 1493-1496. http://dx.doi.org/10.1094/PDIS-92-11-1493

Orawu, M., Melis, R., Demilliano, W., Laing, M., \& Adipala, E. (2005). Occurrence and prevalence of cowpea virus diseases in Uganda. African Crop Science Proceedings, 7, 1279-1283.

Orawu, M. (2007). Occurrence of cowpea aphid borne mosaic virus and prospects of improving resistance in local cowpea landraces in Uganda. Doctoral thesis, African Centre for Crop Improvement, University of Kwazulu-Natal South Africa.

Orawu, M., Melis, R., Laing, M., \& Derera, J. (2012). Genetic inheritance of resistance to cowpea aphid-borne mosaic virus in cowpea. Euphytica, 189(2), 191-201. http://dx.doi.org/10.1007/s10681-012-0756-3

Raheja, A. K., \& Leleji, O. I. (1974). An aphid borne mosaic disease of irrigated cowpeas in northern Nigeria. Plant Disease Reporter, 58, 1080-1084. 
Schuerger, A. C., \& Hammer, M. (1995). Effects of temperature on disease development of tomato mosaic virus in Capsicum annuum in hydroponic systems. Plant Dis., 79, 880-885. http://dx.doi.org/10.1094/PD-79-0880

Singh, B. B., Ehlers, J. D., Sharma, B., \& Freire Filho, F. R. (2002). Recent progress in cowpea breeding. In C. A. Fatokun, S. A. Tarawali, B. B. Singh, P. M. Kormawa, \& M. Tamò (Eds.), Challenges and opportunities for enhancing sustainable cowpea production (pp. 21-40). Proceedings of the World Cowpea Conference III held at the International Institute of Tropical Agriculture (IITA), Ibadan, Nigeria.

Shoyinka, S. A., Thottappilly, G., Adebayo, G. G., \& Anno-nyako, F. O. (1997). Survey on cowpea virus incidence and distribution in Nigeria. International Journal of Pest Management, 43(2), 127-132. http://dx.doi.org/10.1080/096708797228816

Tarawali, S. A., Singh, B. B., Gupta, S. C., Tabo, R., Harris, F., Nokoe, S., ... Odion, E. C. (2002). Cowpea as a key factor for a new approach to integrated crop - livestock systems research in the dry savannas of West Africa. In C. A. Fatokun, S. A. Tarawali, B. B. Singh, P. M. Kormawa, \& M. Tamò (Eds.), Challenges and opportunities for enhancing sustainable cowpea production (pp. 233-251). Proceedings of the World Cowpea Conference III held at the International Institute of Tropical Agriculture (IITA), Ibadan, Nigeria.

Thottappily, G., \& Rossel, H. W. (1985). World-wide occurrence and distribution of virus diseases. In S. R. Singh \& K. O. Rachie (Eds.), Cowpea Research, Production and Utilization (pp. 155-171). John wiley and sons, Chichester, UK.

Timko, M. P., Ehlers, J. D., \& Roberts, P. A. (2007a). Cowpea. In C. Kole (Ed.), Genome Mapping and Moleclular Breeding in Plants (Volume 3, Chapter 3, Pulses, Sugar and Tuber Crops). Berlin: Springer-Verlag.

Patterson, H. D., \& Williams, E. R. (1976a). A new class of resolvable incomplete block designs. Biometrika, 63, 83-92. http://dx.doi.org/10.1093/biomet/63.1.83

R Core Team. (2014). R: A language and environment for statistical computing. R Foundation for Statistical Computing, Vienna, Austria. Retrieved from http://www.R-project.org/

Umaharan, P., Ariyanayagam, R. P., \& Haque, S. Q. (1997). Resistance to cowpea severe mosaic virus, determined by three dosage dependent genes in Vigna unquiculata L. Walp. Euphytica, 95, 49-55. http://dx.doi.org/10.1023/A:1002988003402

Wortmann, C. S., \& Eledu, C. A. (1999). Uganda's Agroecological Zones: A guide for planners and policy makers (pp. 1-59). Centro Internacional de Agricultura Tropical. Quick Color Print, Kampala, Uganda.

\section{Copyrights}

Copyright for this article is retained by the author(s), with first publication rights granted to the journal.

This is an open-access article distributed under the terms and conditions of the Creative Commons Attribution license (http://creativecommons.org/licenses/by/3.0/). 